\title{
Identification of Factors Contributed to Beef Cattle Reproductive Disorders in Ogan Komering Ulu Timur Regency (OKU Timur) of South Sumatra Province in UPSUS SIWAB Program 2018
}

\author{
Vony Armelia, Dadang Mulyadi Saleh and Novie Andri Setianto*) \\ Animal Science Faculty, Jenderal Soedirman University, Purwokerto \\ *Corresponding author email: novie.setianto@unsoed.ac.id
}

\begin{abstract}
The research aimed to identify the factors contributed to reproductive disorders of beef cattle, mapping the factors that affect reproductive disorders of beef cattle and generate strategies to improve reproductive performance of beef cattle in OKU Timur Regency. Participants of the study include 40 beef cattle breeders, inseminators and employees of the Local Office of Fisheries and Livestock Services of OKU Timur Regency. The research was done by survey, the method used was qualitative modeling with the Causal Loop Diagram (CLD). The variables observed in the study were variables related to reproductive performance which are Body Condition Score (BCS), Calving Interval (CI), Service per Conception (S/C), Conception Rate (CR) and variables related to factors indicated to have contribution to reproductive disorders such as farmer characteristics, resources owned by farmers and resources possessed by inseminators. The identified reproductive disorders of beef cattle in OKU Timur Regency includes ovarian hypofunction, endometritis, pyometra, systolic ovary, silent heat, vulvitis, vaginitis, mummification and placental retention. The identified factors contributed to reproductive disorders are low quality and availability of feed, low breeders' knowledge, absence of postpartum treatment, limited medical supplies and quantity, unstandard technical implementation of artificial insemination, cross breeding of heifer, insufficient inseminator facilities. Strategies that can be done to improve the reproductive performance of beef cattle is to increase the role of the government in providing superior feed seeds and assisting by Universities; increasing the number of medicalsupplies and facilities, equip inseminator with sufficient facilities, and technical insemination and increasing the intensity of extension services to improve farmers' knowledge and utilization of potential agricultural waste with technology.
\end{abstract}

Keywords : reproductive disorders, beef cattle, UPSUS SIWAB.

\begin{abstract}
Abstrak. Penelitian ini dilaksanakan untuk mengidentifikasi factor penyebab gangguan reproduksi sapi potong, memetakan faktor yang mempengaruhi gangguan reproduksi sapi potong dan mengidentifikasi strategi meningkatkan performan reproduksi sapi potong di Kabupaten OKU Timur. Penelitian melibatkan 40 peternak sapi potong, petugas inseminator dan pegawai Dinas Perikanan dan Peternakan Kabupaten OKU Timur. Penelitian ini dilakukan dengan survey untuk menyusun kualitatif modelling dengan Causal Loop Diagram (CLD). Variabel yang diamati yaitu variable terkait performan reproduksi yang terdiri atas Body Condition Score (BCS), Calving Interval (CI), Service per Conception (S/C), Conception Rate (CR) dan variable terkait faktor yang diduga berkontribusi terhadap gangguan reproduksi terdiri atas karakteristik peternak, sumberdaya yang dimiliki peternak dan sumberdaya yang dimiliki inseminator. Hasil penelitian menunjukkan bahwa gangguan reproduksi pada ternak sapi potong di Kabupaten OKU Timur diantaranya adalah hipofungsi ovarium, endometritis, piometra, sistic ovary, silent heat, vulvitis, vaginitis, mumifikasi dan retensi plasenta. Penyebab gangguan reproduksi yaitu rendahnya kualitas dan ketersediaan pakan, pengetahuan peternak yang rendah, tidak adanya penanganan postpartus, fasilitas dan jumlah medis yang terbatas, teknis pelaksanaan inseminasi buatan yang tidak sesuai standard pelaksanaan, cross breeding pada ternak dara, fasilitas inseminator yang belummencukupi kebutuhan. Strategi yang dapat dilakukan untuk meningkatkan performan reproduksi sapi potong yaitu meningkatkan peran pemerintah menyediakan bibit pakan unggul dan pendampingan dengan perguruan tinggi; meningkatkan jumlah medis, fasilitas medis, fasilitas inseminator, dan teknis inseminasi serta meningkatkan intensitas penyuluhan guna meningkatkan pengetahuan peternak dan pemanfaatan potensi limbah pertanian dengan teknologi.
\end{abstract}

Kata kunci : gangguan reproduksi, sapi potong, UPSUS SIWAB.

\section{Introduction}

OKU Timur Regency in South Sumatra Province is one of the target areas for the
UPSUS SIWAB (Special Efforts Of Mandatory Cattle Breeding). In 2017, cow population in OKU Timur Regency was recorded at 66,884, 
2,500 of which were used as receptors and reported as many as 817 were indicated to have reproductive disorders (Local Office of Fisheries and Livestock Services of OKU Timur Regency, 2018).

The key point to breed beef cattle populations is reproductive health of the livestock. To support the success of the SIWAB UPSUS program, the reproductive health status of livestock is very important (Bukittinggi Veterinary Center, 2014). Parental reproductive disorders can reduce brood cow performance so that it can reduce the beef cattle population in East OKU District.

In the graph of agricultural business households in South Sumatra Province (BPS, 2013), the livestock sector ranking is in $3^{\text {rd }}$ place. It shows that most people in the South Sumatra Province are engaged in livestock business. The development and population of livestock in the OKU Timur Regency becomes the highest position in the South Sumatra region (BPS, 2016). The large population is an indicator that can make OKU Timur becoming a self-sufficient district for meat in the next few years.

A total of $32.68 \%$ of the Beef cattle population in OKU Timur Regency is suspected of having reproductive disorders (Local Office of Fisheries and Livestock Services of OKU Timur Regency, 2018). Therefore, it is needed to perform an identification to find out various factors that cause reproductive disorders and figure out the relationship between the factors that influence them. the identification of these various factors is important to be done to design strategies to improve reproductive health of beef cattle.

\section{Materials and Method}

The objectives in the study were Beef cattle breeders, Inseminator, Local Office of Fisheries and Livestock Services of OKU Timur Regency. Furthermore, this study was carried out at Semendawai Suku III and Semendawai Timur,
OKU Timur Regency, South Sumatra. This study was conducted by survey in which the method used was Qualitative Modeling with Causal Loop Diagram (CLD). Qualiltative modelling using CLD has been conducted by Setianto et al (2014a, 2014b, 2014c) in developing strategies for beef development. The variables observed in the study were the variables related to reproductive performance in which it consists of Body Condition Score (BCS), Calving Interval $(\mathrm{Cl})$, Service per Conception (S/C), Conception Rate (CR) and variables related to factors suspected having a contribution to reproductive disorders in which it consists of breeders characteristics, resources owned by breeders, and resources owned by inseminators

\section{Results and Discussion}

\section{Reproductive Performance}

As many as $37.50 \%$ of beef cattle samples in OKU Timurthat have reproductive disorders have ideal BCS in which it is 3 . The remaining of those are $63.50 \%$ having BCS 2-2.5 with an average of 2.58. Budiawan et al. (2015) in his study on the relationship between BCS to S/C and $\mathrm{Cl}$ of beef cattle PO in Babat Sub-district, Lamongan District stated that BCS in beef cattle was influenced by feed factors and maintenance management. BCS contributes to $\mathrm{S} / \mathrm{C}$ and $\mathrm{Cl}$, so if the $\mathrm{BCS}$ value is not ideal, it will increase the $\mathrm{S} / \mathrm{C}$ and $\mathrm{Cl}$ numbers in livestock. Livestock with body weight that exceeds and is less than the ideal body weight will have an impact on the reproductive system causing failure in the first marriage so that the S/C number becomes high and $\mathrm{Cl}$ becomes extensive. Based on study location observations, from several of these factors that contribute to BCS numbers, namely the feed factor.beef cattle breeders provide feed field grass for animals in ad libitum without considering the amount of livestock needs.

Calving Interval in beef cattle in OKU Timur Regency is $14-24$ months with an average of 
16.75 months. Toelihere (1993) stated that the factors causing breeding range to be longer are the age of calf weaning, age at first mating, and improper marriage due to detection of late lust. Hastuti et al. (2008) in their study on the socioeconomic implementation of IB beef cattle inKebumenRegency stated that the factors influencing $\mathrm{Cl}$ numbers are the delay in mating livestock after breeding. Based on study location observations, is showed that the factors causing high numbers of $\mathrm{Cl}$ in livestock are the delay of lust after breeding animals and mated livestock $<60$ days after breeding. Susanti, et al. (2015) stated that brood cow fertility occurs in range of 60 to 90 days after breeding so that the right time to do the next mating is age of 60 days after breeding to produce an ideal $\mathrm{Cl}$ value of 12 months. Pirlo et al. (2000) stated that the delay in the first lust after briding was due to errors in lust detection, lack of body weight, and environmental factors.

$\mathrm{S} / \mathrm{C}$ numbers indicating brood cow fertility are 1-2. It showed that there will be one pregnancy of livestock in one or two mating (Budiawan et al., 2015). The S/C number obtained based on the survey results reached 210x of mating to produce one pregnancy. The average $\mathrm{S} / \mathrm{C}$ number of Beef cattle in OKU Timur Regency is 4.38. Ihsan and Wahjuningsing (2011) in their study on the reproductive appearance of Beef cattle in BojonegoroRegency stated that the factors influencing the $S / C$ number in Beef cattle included the length of sexual lust after breeding, excessive use of labor to cultivate land and lack of attention of breeders to livestock lust and asking for mating, being the causes the late of cow's matting, and another factor in which it is the interval between the occurrence of the first lust. Based on study location observations, from several of these factors that contribute to $S / C$ were the detection of improper lust by breeders, Silent Heat and anestrus in livestock.
Conception Rate Number of livestocks experiencing reproductive disorders based on study data is $5 \%$. The number is below the ideal $\mathrm{CR}$ value standard which is above $60 \%$ according to Ihsan and Wahjuningsih (2011). Suharyati and Hartono (2015) in their study on the reproductive efficiency of Bali Cow in Pringsewu, Lampung Province, stated that the factors influencing the low CR value are breeders' knowledge about the age of first mating, cage sanitation, and feeding. Based on study location observations, from several of these factors that contribute to the CR high value is the first mating time of the livestock. Breeders mate their livestock during sexual maturity or when the first signs of lust occurred without considering the condition of the animal body. Based on the results of discussions with breeders, this is done so that breeders get income early and quickly. Breeders have not yet realized the negative effects of premature mating on livestock. According to Suharyati and Hartono (2015), they stated that if the livestock is in new puberty and is not ready for sex $(<18$ months) being mated, it will cause low fertility levels. it is because the nutrients that enter the body are still used for the main function or the body growth.

Based on the results of the $t$ test between reproductive performance consisting of $B C S$, $\mathrm{S} / \mathrm{C}, \mathrm{Cl}$, and $\mathrm{CR}$ in District $\mathrm{A}$ and District $\mathrm{B}$ with different access, the value of $t$ arithmetic $<t$ table. It showed that there are no significant differences between the reproductive performance of Beef cattle with $\mathrm{BCS}, \mathrm{S} / \mathrm{C}, \mathrm{Cl}$, and $C R$ indicators in the Districts with easy access and with difficult access. Based on study location observations, it showed that the BCS, $\mathrm{S} / \mathrm{C}, \mathrm{Cl}$, and $\mathrm{CR}$ values were influenced by maintenance management and the artificial insemination techniques. There is no difference in feed provided and maintenance management in areas with easy and difficult access. According to the inseminator, road access is not an obstacle in implementing insemination 
because areas with easy and difficult access can still be reached by motorized vehicles.

\section{Breeder Characteristic}

Breeders characteristic in East OKU District are assessed based on age, education level, demography, occupation, and economic status of breeders. The average age of breeders in OKU Timur Regency is 31 to 70 years. According to Otampi et al. (2017), they stated that nonproductive age for raising livestock is 65 years. Based on the results of a survey on the study location, it is as many as $5 \%$ of breeders have age above 65 years. It showed that most breeders in OKU Timur Regency are in the productive age group to work and run a livestock business.

Most breeders (60\%) in OKU Timur Regency graduate from elementary school with a number of family members $<5$ people per household. According to Suharyati and Hartono (2015), they stated that breeders who have high education will find it easier to receive good knowledge about raising livestock. Breeders knowledge about good maintenance management and reproductive management will improve reproductive efficiency. According to Prasetyo (2016), he stated that the increasing number of family members will be an economic burden for breeders. On the other hand, the number of family members will provide worker for the livestock business that is run.

Based on the survey results of 40-breeder respondents, all breeders stated that livestock business is an activity to fill a hobby after farming, and it is as a savings. Utomo and Miranti (2010) stated that livestock business is a branch of farming from an integrated farming system. Livestock as a subsystem of agriculture is a complex system because it is a multiactivity, multi-objective, and stake holder that is a characteristic of a people's livestock, so it requires a complex system and needs to be further studied by modeling.
The breeders' economic status with ownership of 1-4 beef cattle is fairly low. Based on information from breeders, the income obtained from raising livestock with the number of 1-4 beef cattle ranges from Rp.100,000.00 to Rp.400,000 per month depending on the nation's livestock and the amount of livestock ownership. This income does not include the salary for labor, feed provided, and medical expenses if the animal is sick. It is in accordance with the research conducted by Riszqina et al. (2011) stated that livestock business with a small scale of business has not provided high profits for breeders. Based on study location observations, the breeders in East OKU District came from middle-income groups, so that they did not take considering the income obtained from raising livestock. The livestock raised is used as savings when needed by livestock owners.

Another obstacle experienced by breeders is the lack of counseling from the official Agency to breeders related to the importance of postpartum handling in livestock, so that after the livestock breed, no handling is carried out. It can cause an infection in livestock which can cause reproductive disorders. According to Law No. 16 of 2006 concerning about Counseling stated that the quantity of extension activities is 16 times in a month. Mustakim (2015) added that the intensity of the implementation of ideal counseling is $>4 x$ in a month. Therefore, the increasing of counseling role must always be improved, so that it will in line with the improvement the breeder's quality.

\section{Resources owned by breeders}

Resources owned by breeders are measured based on feed, number of livestock ownership, and human resources or worker owned by breeders. Feed given to beef cattle in people's livestock is agricultural waste or weeds (Lestariningsih, et al. 2008). The feed given to beef cattle in OKU Timur Regency is field grass. In the rice harvest season, breeders use 
additional concentrate in the form of bran, and they graze their livestock in dry fields so that the feed consumed is straw. The extensive land in OKU Timur Regency is not being used optimally by breeders to grow forage, even though the local official Agency has provided the Pilot of Forage Animal Feed (HMT) and Animal Feed Development.

Based on the survey results, all respondents stated that they did not need additional labor to raise livestock of 1-4. The low number of livestock ownership is due to the limited number of workers to find food and raise livestock. The workers come from family members. Breeders look for grass before and after completing farming activities, in the morning and evening. This is in accordance with Murwanto's (2008) statement that the number of ownerships per household of small holder farmers in Indonesia is 1-5. Family members are a labor source for a people's livestock (Lestariningsih et al., 2008).

\section{Resources owned by Inseminator}

The resources owned by the inseminator in OKU Timur Regency were measured based on the facilities possessed by the inseminator and the ratio of farmers and inseminators as well as the coverage of areas that must be served by an inseminator. The problems that occur at the inseminator level are still difficult to meet the need of straw and N2 liquid, so that supporting facilities and infrastructure are needed (Rusdiana and Soeharso, 2017). According to information from the inseminator in OKU Timur Regency, inseminator facilities are still not enough to be able to implement insemination standard operation procedure (SOP) properly. Inseminator stated that there was no assistance in field containers and that the amount of N2 was still limited so that the maintenance of seeds or cement became poor causing high seed mortality during the trip. The number of plastic sheets is also an obstacle for the inseminator in the implementation. One plastic sheet is used for several livestock. According to inseminator, the availability of plastic sheets refers to the number of animals inseminated in the previous month reported by the inseminator. This is considered as a cause transmission of reproductive diseases among livestock.

Another obstacle faced by the inseminator was the demand for certain types of straw by breeders. it caused cross-breeding between cattle that occurred in this region to be quite high. Local livestock that are still virgin are inseminated with imported cow which causes the possibility of dystocia at breeding which can cause reproductive disorders in beef cattle. According to Diwyanto and Inounu (2009), they stated that crossbred cattle are often encountered experiencing abnormal estrus cycles, such as short estrus cycles, long estrus cycles, split estrus, nymphomania, and silent estrus or quite ovulation. Theoretically, crossbred cattle as a result of IB have a larger body size. As a consequence, the need for feed for maintenance is far greater than for smaller cattle.

The ratio of breeders and inseminators in OKU Timur in 2018 is 1: 241 . The ratio shows that in 365 days, an inseminator can carry out livestock insemination on 241 breeder families or 20.08 livestock per month with a total of 1-4 beef cattle per breeder family. According to study by Fadhil et al. (2017), the stated that the inseminator can handle the average number of acceptors every month, which is $36 \pm 19.25$, with a distance to the acceptor of $4.23 \pm 3.38$ $\mathrm{km}$. It shows that the number of inseminators in OKU Timur Regency has sufficient needs.

Topography or hard-to-reach working areas and distance barriers are obstacles faced by inseminators (Rasad et al., 2008). According to the Local Office of Fisheries and Livestock Services of OKU Timur Regency, the inseminator working area is in one sub-district. In its implementation, the inseminator assigned outside his work area in which it reached 4 sub- 
districts. Based on discussions with the inseminator, this was due to breeders' trust factors. According to the information from the inseminator in OKU Timur Regency, an inseminator could mate 1-12 cattle/ a day with a distance of $0-70 \mathrm{~km}$ reaching a 2-hour journey. The complete qualitative modeling of the reproductive disorder is presented in Figure 1. Based on the modeling analysis, several loops were identified as follows.

\section{Feed loop.}

The loop diagram in Figure 2. consists of loops R1 and B3. Loop R1 explains that the rate is positively affected by the variable feed reproductive health - breeding - population sales - economic conditions - forage land availability of forage. Availability of forage that adequately improves reproductive health of livestock. Reproductive health increases the breeding rate of livestock. The breeding of livestock causes the livestock population to increase. The high population increases livestock sales. Livestock sales increase the breeders' economy. The increase of breeders economic conditions have made the amount of forage land more widespread. Loop B3 explains that the efforts to increase population are influenced by variable feed requirements. Feed requirements reduce feed availability. Availability of feed improves reproductive health in livestock. Reproductive health increases the number of livestock populations. Livestock population increases the needs of animal feed. Based on this, the strategy that can be done to improve the beef cattle reproductive health status in OKU Timur Regency is the counseling about animal feed so that breeders' knowledge increases in which it is in line with the increase in the availability of animal feed and the development of technology in utilizing agricultural waste in the study area.

\section{Breeding and death loop}

Figure 3. consists of loops B1 and R2. Loop R2 explains that breed will increase livestock population. Livestock population will increase breeding rates of livestock. Loop B1 explains the balance between livestock mortality and livestock population. Death causes a population decrease of livestock. Livestock population will increase mortality of livestock. The effort that has been carried out by the local government to increase beef cattle populations is to increase livestock breeding rates by improving reproductive health of livestock. Based on loop $B 1$ and R2, efforts that can be made to increase the population of beef cattle in East OKU Regency not only increase the breeding rate of livestock, but by reducing mortality rates of livestock.

\section{Livestock breeding and sales}

Figure 4.consists of loops B2 and R2. Loop R2 explains that breeding will increase livestock population. Livestock population will increase breeding rates in livestock. Loop B2 explains the balance between the number of livestock populations and the level of livestock sales. The sale of livestock causes the number of livestock population to decline. The livestock population causes the rate of livestock sales to increase. Based on the R2 and B2 loops, efforts that can be made to increase the number of livestock populations is to increase the breeding rate and to reduce the number of livestock sales. However, reducing the number of livestock sales will reduce breeders' income. Thus, it reduced the ability to provide medical facilities that have an impact on reducing reproductive health of livestock in OKU Timur seen from loop R3. Suppressing the needs of breeders' household is a solution to reduce livestock sales number so that they do not cause a decline in breeders' economic conditions. 


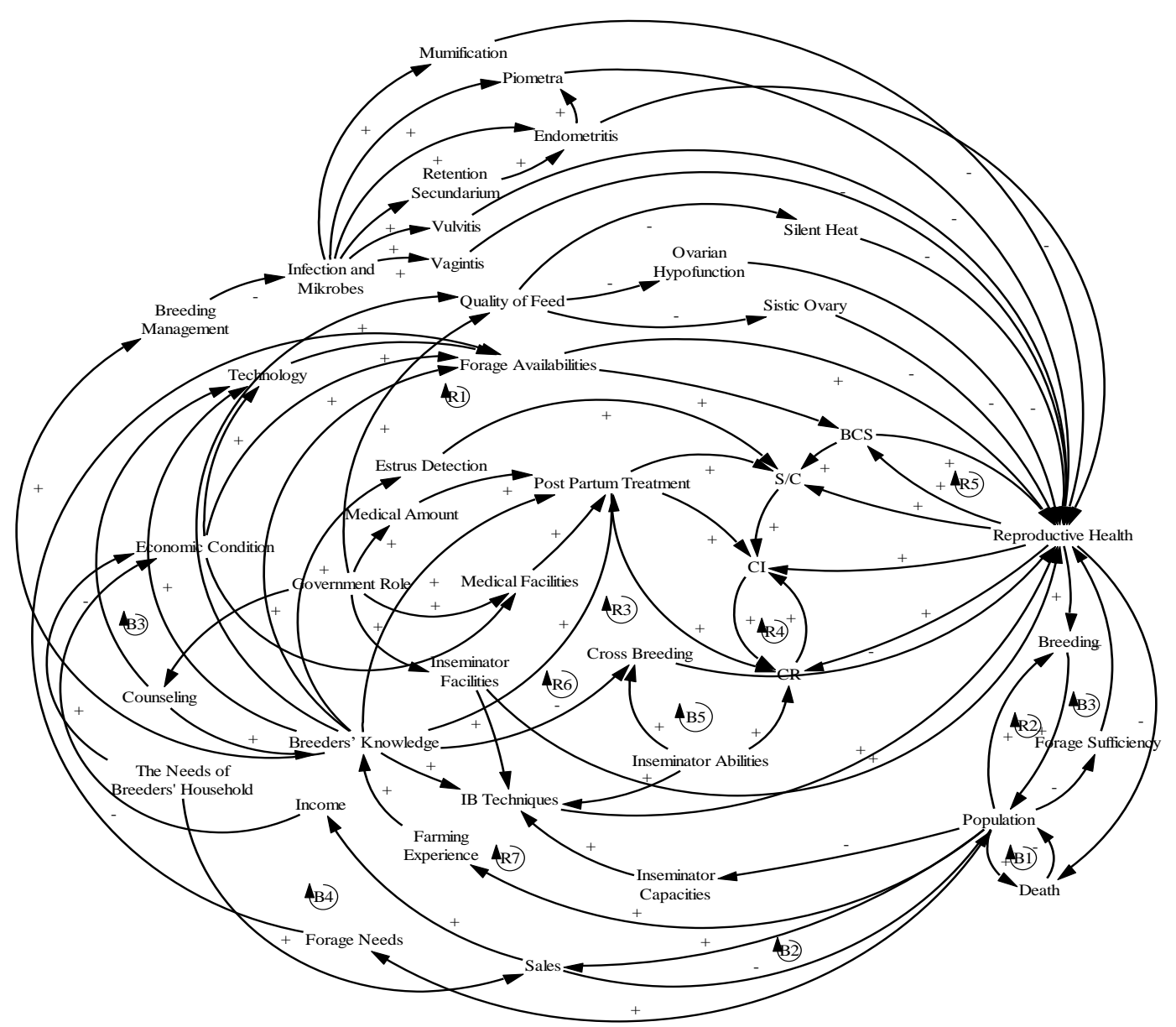

Figure 1. Causal Loop Diagram of Reproductive Disorder

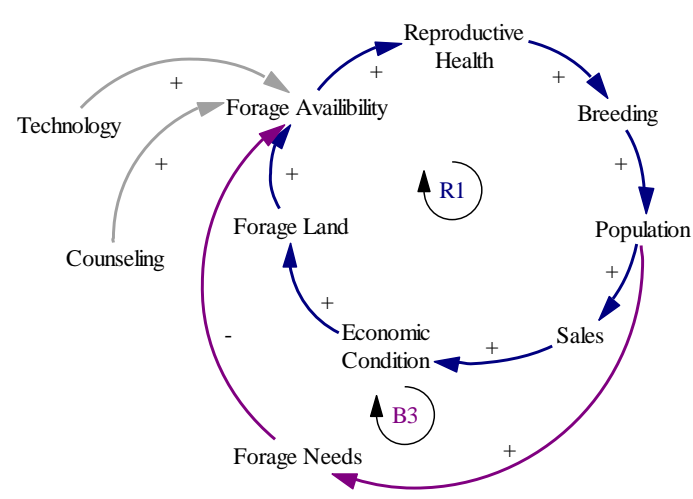

Figure 2. Feed Loop

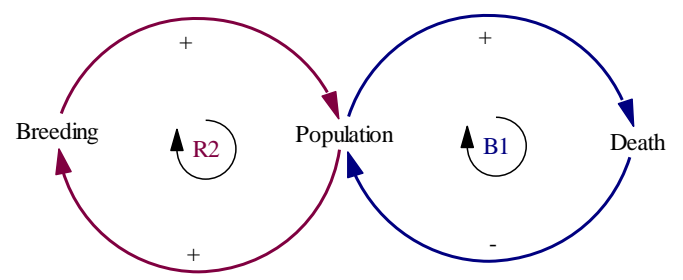

Figure 3. Breeding and Death Loop

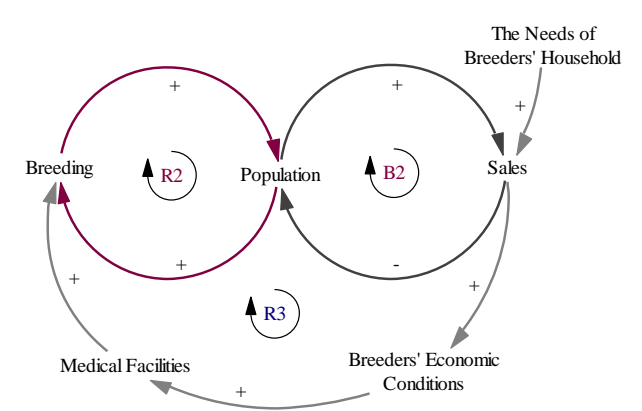

Figure 4. Breeding and Sales Loop

\section{Forage Availability, Postpartum Treatment and Technology}

Figure 5.consists of loop diagrams B3, R3 and R9. Loop B3 explains that the higher the level of forage, the more the population increases. High population numbers increase the amount of forage needs. The increasing 
need for livestock causes a decrease in the amount of forage availability.

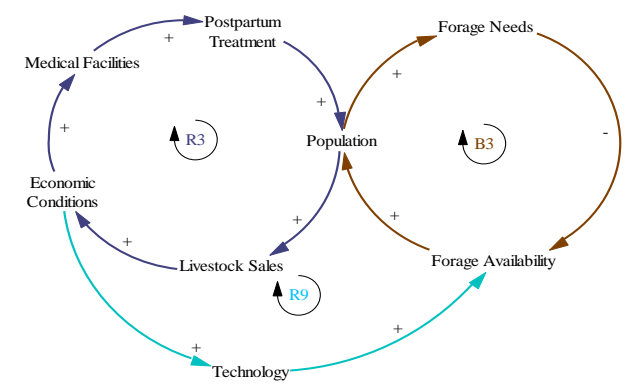

Figure 5. Forage Availability, Postpartum Treatment and Technology Loop

Loop R3 explains the rate is positively affected by postpartum treatment - population - livestock sales - economic conditions - medical facilities. Postpartum treatment will cause an increase in population. The increasing number of populations causes the livestock sale to be higher. Livestock sales increase the breeders' economy. Breeders' economic increase the availability of providing medical facilities. Based on Loop R9, it is explained that in long term, technology will be a solution for increasing the number of livestock populations. Technology will increase the amount of forage availability, thereby encouraging population growth in livestock. Technology will help to increase the livestock population so that the economic conditions of breeders increase, and it encourage the ability of breeders to provide medical facilities to improve reproductive health of livestock.

\section{Reproductive Performance}

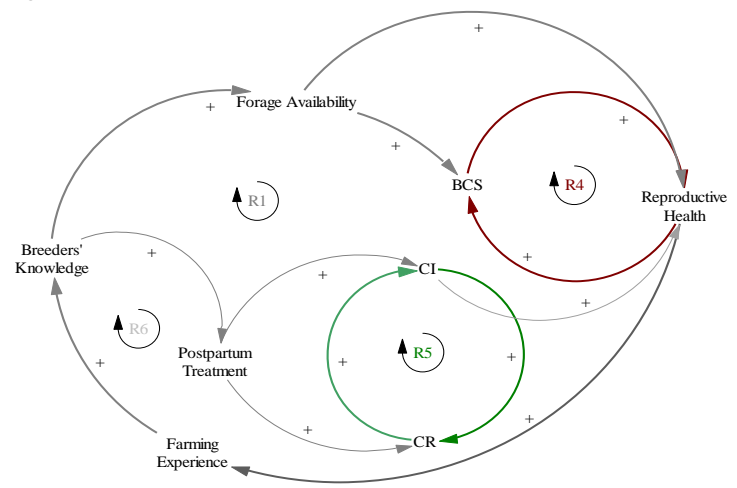

Figure 6. Reproductive Performance and Breeders' Knowledge
Figure 5. consists of loops R4 and R5. Loop R4 explains the relationship between BCS and reproductive health. The ideal BCS number for livestock improves reproductive health of livestock. The high reproductive health status causes BCS numbers of livestock to be ideal. Loop R5 explains that ideal $\mathrm{Cl}$ numbers cause $\mathrm{CR}$ numbers to be ideal. The ideal $C R$ number causes $\mathrm{Cl}$ numbers to be ideal. The ideal $\mathrm{Cl}$ number improves reproductive health of livestock. It shows that $\mathrm{Cl}$ and $\mathrm{CR}$ represent good reproductive health of livestock. Based on the loop R4 and R5, both are derived from the loop R6, namely the level of breeders' knowledge. Therefore, a strategy that can be done to improve reproductive health of livestock is to increase breeders' knowledge about animal reproduction. Knowledge of breeders improves postpartum treatment and availability of animal feed, causing $\mathrm{BCS}, \mathrm{Cl}$, and $\mathrm{CR}$ numbers of livestock to be ideal so as to improve reproductive health of livestock.

\section{Cross-Breeding}

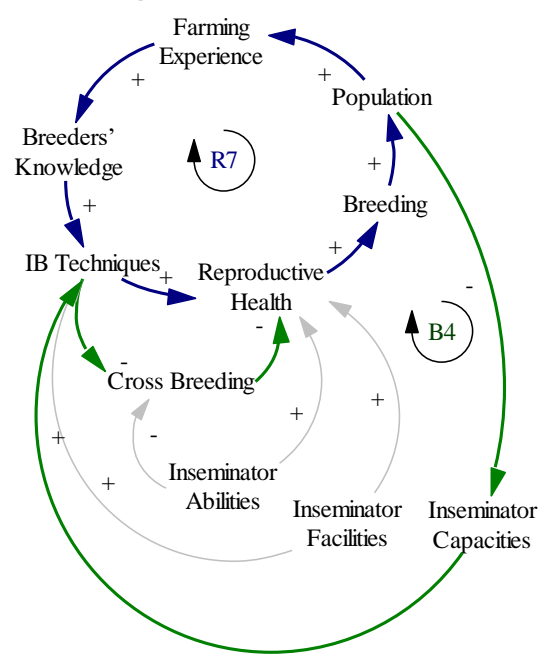

Figure 7. Breeders' Knowledge and CrossBreeding

Figure 7.consists of loops B4 and R8. Loop B4 explains that cross-breeding in livestock decreases reproductive health in livestock. Reproductive health of livestock increases the breeding rate of livestock. Animal breeding 
rates increase the population of livestock. Increasing population size causes decreasing inseminator capacity. Inseminator capacity improves the technical service of the IB. Loop R8 explains the loop rate positively affected by the breeders' knowledge - IB techniques reproductive health - breeding - population breeder experience. Breeders' knowledge enhancing IB techniques is getting better. IB techniques improve reproductive health of livestock. Reproductive health of livestock increases the breeding rate. The breeding of livestock increases the population. The increasing number of populations causes the experience of farming to increase. Based on loops B4 and R8, a strategy that can be done to improve the reproductive health status of livestock is to increase breeders' knowledge, to reduce cross-breeding rates of livestock, and to increase the capacity of inseminators.

\section{Government Role and Counseling}

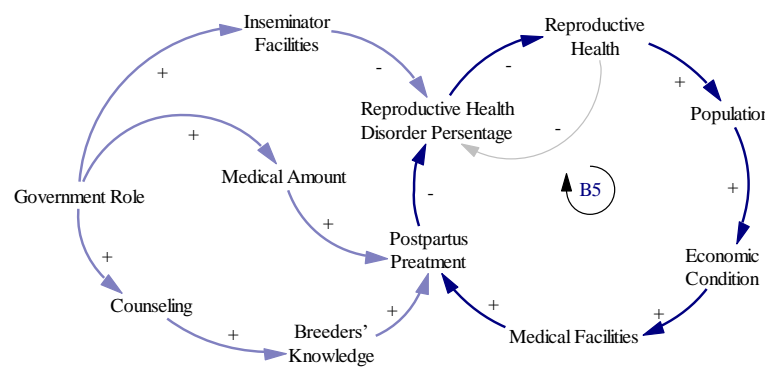

Figure 8. Government Role and Counseling Loop

According to study respondents' information, problems that occurred at the breeder and inseminator level are postpartum implementation that is not carried out because of the lack of breeders' knowledge and inseminator facilities that are not yet complete enough to allow the transmission of reproductive diseases in livestock through repeated plastic sheets. The government role in increasing the number of medical personnel and inseminator facilities will help to improve postpartum treatment for livestock and reduce the percentage of reproductive disorders of livestock. Based on Figure 8., the government role in the form of counseling will be a solution to increase breeders' knowledge about the importance of postpartum treatment, so that it will reduce the reproductive disorders percentage and improve reproductive health of livestock.

\section{Model Discussion}

Based on the modeling analysis, the problems caused by reproductive disorders in beef cattle in OKU Timur Regency were:

1. The low quality of animal feed and animal feed that does not need to reproduce

2. Lack of breeder's knowledge regarding to the maintenance management, reproductive health of livestock, and inappropriate lust detection

3. Absence of handling for postpartum of livestock

4. Facilities and number of medical personnel are limited

5. The technical implementation of artificial insemination is thawing which is not in accordance with the standards for the insemination implementation

6. Cross-breeding on Heifer

7. Inseminator work facilities that are field containers, liquid N2 and plastic sheets are not sufficient.

Based on these problems, the strategies that can be done to improve the reproductive performance of beef cattle in OKU Timur Regency are:

1. Increasing the government role in providing superior grass seed and legumes as a substitute for livestock concentrates through collaboration with animal feed nurseries, as well as assistance with universities because quality feeds will reduce the percentage of reproductive disorders of livestock.

2. Increasing the government role as it will have an impact on the availability of medical practitioners (veterinarians and ATR), medical facilities, inseminator 
facilities (field containers, liquid nitrogen, and plastic sheets), technical insemination so as to improve the handling of livestock health and minimize reproductive disorders.

3. Increasing the intensity of counseling because it will have an impact on breeders' knowledge regarding postpartum treatment, cross-breeding of wild cattle, the implementation of artificial insemination, lust detection; and availability of animal feed so that breeders will improve maintenance management and improve livestock reproductive performance.

4. Counseling about the utilization of potential agricultural waste with feed technology because it will have an impact on increasing the availability of animal feed so as to produce ideal BCS numbers.

\section{Conclusions}

The study able to identify reproductive disorders which include ovarian hypofunction, endometritis, pyometra, ovaria cyst, silent heat, villitis, vaginitis, secondary mummification and retention with symptoms such as recurrent mating, miscarriage, uterine prolapses, calm lust, placental retention and anestrus. These was suspected as a result of insufficient feed, breeder's knowledge, postpartum handling, inseminator facilities, number of medical facilities, technical insemination, and crossbreeding livestock.

The strategies that can be recommended to improve reproductive performance of livestock are improving animal feed quality, maintenance management, feed technology, lust detection, postpartum treatment, reducing the risk of cross-breeding in wild cattle through counseling and the application of feed technology. Also to local government by increasing inseminator facilities, medical facilities, and increasing the number of medical personnel will support the improvement of reproductive health of livestock.

\section{References}

Badan Pusat Statistik. 2013. Grafik Rumah Tangga Usaha Pertanian di Provinsi Sumatera Selatan. BPS Provinsi Sumatera Selatan. Palembang.

Badan Pusat Statistik. 2016. Populasi Ternak Sapi di Sumatera Selatan. BPS Provinsi Sumatera Selatan. Palembang.

Balai Veteriner Bukittinggi, Kementerian Pertanian, Direkrorat Jenderal Peternakan dan Kesehatan Hewan. 2014. Laporan Pelaksanaan Kegiatan Penanggulangan Penyakit Gangguan Reproduksi pada Sapi Potong No. 530.

Budiawan, A., M. N. Ihsan dan S. Wahjuningsih. 2015. Hubungan Body Condition Score Terhadap Service perConception dan Calving Interval Sapi Potong Peranakan Ongole di Kecamatan Babat Kabupaten Lamongan. J. Ternak Tropika 16(1): 34-40.

Dinas Perikanan dan Peternakan OKU Timur. 2018. Laporan Populasi Hewan Ternak Menurut Jenis Ternak dan Kecamatan di Kabupaten OKU Timur Tahun 2017. OKU Timur, Sumatera Selatan.

Diwyanto, K dan I. Inounu. 2009. Dampak Crossbreeding dalam Program Inseminasi Buatan Terhadap Kinerja Reproduksi dan Budidaya Sapi Potong. WARTAZOA 19(2): 93-102.

Fadhil, M., M. Hartono dan S. Suharyati. 2017. Faktor-Faktor yang Memengaruhi Conception Rate Sapi Perah pada Peternakan Rakyat di Provinsi Lampung. Jurnal Penelitian Peternakan Indonesia 1(1): 1-7.

Hastuti, D. 2008. Kajian sosial ekonomi pelaksanaan inseminasi buatan sapi potong di Kabupaten Kebumen. Tesis. Universitas Gadjah Mada.

Ihsan, M. N dan S. Wahjuningsih.2011. Penampilan Reproduksi Sapi Potong di Kabupaten Bojonegoro. J. TernakTropikal 12(2): 76-80.

Lestariningsih, M., Basukidan Y. Endang.2008. Peran serta Wanita Peternak Sapi Perah dalam Meningkatkan Taraf Hidup Keluarga. Ekuitas 12(1): 121-141.

Murwanto, A. G. 2008. KarakteristikPeternakdan Tingkat Masukan Teknologi Peternakan Sapi Potong di Lembah Prafi Kabupaten Manokwari. Jurnal Ilmu Peternakan 3(1): 8-15.

Mustakim, M. B. 2015. Pengaruh Intensitas Penyuluhan dan Tingkat Pengetahuan Terhadap Persepsi Peternak pada Teknologi Biogas di Desa Patalassang Kecamatan Tompobulu Kabupaten Bantaeng. Skripsi. Universitas Hasanuddin. Makassar. 
Otampi, R. S., F. H. Elly., M. A. Manesedan G. D. Lenzun. 2017. Pengaruh Harga Pakan dan Upah Tenaga Kerja Terhadap Usaha Ternak Sapi Potong Petani Peternak di Desa Wineru Kecamatan Likupang Timur Kabupaten Minahasa Utara. Jurnal Zootek 37(2): 483-495.

Pirlo, G., F. Milfliordan M. Speroni. 2000. Effect of Age at First Calving on Production Traits and Difference Between Milk Yield and Returns and Rearing Cost in Italian Holsteins. Journal Dairy Science 83(3): 603-608.

Prasetyo, A. F. 2016. Konsumsi Susu Keluarga Peternak Sapi Perah Anggota Koperasi Peternak Sapi Perah Setia Kawan. Jurnal Ilmia hInovasi 16(01): 1-6.

Rasad, S. D., S. Kuswaryan., D. Sartikadan R. Salim. 2008. Kajian Pelaksanaan Program Inseminasi Buatan Sapi Potong di Jawa Barat. Prosiding Seminar Nasional Sapi Potong 2008.

Riszqina., L. Jannah., Isbandi., E. Riantodan S. I. Santoso. 2011. Analisis Pendapatan Peternak Sapi Potong dan Sapi Bakalan Karapan di Pulau Sapudi Kabupaten Sumenep. Jurnal IImu dan Teknologi Peternakan 1(3): 188-193.

Rusdiana, S dan Soeharsono. 2017. Program SIWAB untuk Meningkatkan Populasi Sapi Potong dan Nilai Ekonomi Usaha Ternak. Forum Penelitian Agro Ekonomi 35(2): 125-137.

Setianto, N. A., Cameron, D. \& Gaughan, J. B. 2014a. Identifying Archetypes of an Enhanced System
Dynamics Causal Loop Diagram in Pursuit of Strategies to Improve Smallholder Beef Farming in Java, Indonesia. Systems Research and Behavioral Science, 31: 642-654.

Setianto NA, Cameron D, Gaughan JB. Structuring the problematic situation of smallholder beef farming in Central Java, Indonesia: using systems thinking as an entry point to taming complexity. 2014b. International Journal of Agricultural Management. 2014;3(3):164-74.

Setianto NA, Cameron DC, Gaughan JB. 2014c. Everyday Flux of Smallholder Beef Farming: System Overview of the Beef Farming Situation Under a Government Grant. Animal Production. 2014;16(1):39 - 47

Suharyati, S dan M. Hartono.2015. Pengaruh Manajemen Peternak terhadap Efisiensi Reproduksi Sapi Bali di Kabupaten Pringsewu Provinsi Lampung. Jurnal penelitian Pertanian Terapan 16(1): 61-67.

Susanti, A. E., N. Ngadiyono dan Sumadi. 2015. Estimasi Output Sapi Potong di Lahan Pasang Surut Kabupaten Banyuasin Provinsi Sumatera Selatan. Jurnal Lahan Suboptimal 4(2): 106-116.

Toelihere, M. R. 1993.Fisiologi Reproduksi Ternak. Angkasa. Bandung.

Utomo, B dan Miranti, D. B. 2010.Tampilan Produksi Susu Sapi Perah yang Mendapat Perbaikan Manajemen Pemeliharaan. Cakratani 25(1): 1-5. 